\title{
Growth and yield attributes of Pigeonpea [Cajanus cajan (L.) Millsp.] as influenced by drip irrigation and fertigation levels
}

\author{
G. D. Gadade*, D. N. Gokhale, U. M. Khodke and A. S. Kadale \\ AICRP on Irrigation Water Management, Vasantrao Naik Marathwada Krishi Vidyapeeth, \\ Parbhani (M.S.) - 431 402, India \\ *Corresponding author
}

\section{A B S T R A C T}

Keywords

Pigeonpea, drip irrigation,

fertigation, growth attributes and yield attributes

Article Info

Accepted:

12 May 2021

Available Online:

10 June 2021
Field experiments were conducted for two consecutive years during kharif 2018-19 and 2019-20 to study the effect of drip irrigation and fertigation levels on growth and yield attributes of pigeonpea. The experiment was carried out in split plot design where in four irrigation levels viz. $\mathrm{I}_{1}$ : Drip irrigation at $0.8 \mathrm{ETc}, \mathrm{I}_{2}$ : Drip irrigation at $0.8 \mathrm{ETc}_{3}$ : Drip irrigation at $1.0 \mathrm{ETc}$ and $\mathrm{I}_{4}$ : Conventional method (surface irrigation of $60 \mathrm{~mm}$ each at critical growth stages like bud initiation, flowering and pod formation stage as per the situation) and sub plots were allotted to four fertigation levels viz. $\mathrm{F}_{1}$ : Control (No fertilizer application), $\mathrm{F}_{2}: 80 \%$ RDF $(20: 40: 20 \mathrm{NPK} \mathrm{kg}$ $\left.\mathrm{ha}^{-1}\right), \mathrm{F}_{3}: 100 \% \operatorname{RDF}(25: 50: 25 \mathrm{NPK} \mathrm{kg}$ ha- 1$)$ and $\mathrm{F}_{4}: 120 \% \operatorname{RDF}(30: 60: 30$ NPK $\mathrm{kg} \mathrm{ha}^{-1}$ ) and thus sixteen treatment combinations were replicated thrice. The results of experiment revealed that application of drip irrigation at $1.0 \mathrm{ETc}$ scheduled at alternate day recorded significantly higher growth parameters viz. plant height, number of branches plant ${ }^{-1}$ and total dry matter accumulation plant ${ }^{-1}$ however; it was at par with irrigation level $0.8 \mathrm{ETc}$. While application of drip irrigation at $0.8 \mathrm{ETc}$ scheduled at alternate day recorded significantly higher yield attributes viz. No. of pods plant ${ }^{-1}$, weight of pods plant ${ }^{-1}(\mathrm{~g})$ and seed yield plant $^{-1}(\mathrm{~g})$ over rest of the irrigation levels. Drip fertigation with 30:60:30 NPK kg ha ${ }^{-1}$ (120\% RDF) recorded significantly higher growth parameters like plant height, number of branches plant ${ }^{-1}$ and total dry matter accumulation plant ${ }^{-1}$, however it was at par with $25: 50: 25 \mathrm{NPK} \mathrm{kg}$ $\mathrm{ha}^{-1}(100 \% \mathrm{RDF})$. While application of drip fertigation with 25:50:25 NPK kg ha(100\%RDF) recorded significantly higher yield attributes viz., number of pods plant ${ }^{-1}$, pod weight plant $^{-1}(\mathrm{~g})$ and seed yield plant ${ }^{-1}(\mathrm{~g})$.

\section{Introduction}

Pigeonpea (Cajanus cajan (L.) Millsp.) is the second most important pulse crop of India after chickpea. Pigeonpea cultivation improves soil fertility through nitrogen fixation as well as from the leaf fall and recycling of the nutrients (Snapp et al., 2002) and thus provides $40-60 \mathrm{~kg} \mathrm{~N}^{-1}$ to the subsequently grown crop (Sarkar et al., 2018). At national level Maharashtra ranks first in area (1.04 m.ha) and production (0.47 million 
tonne) of pigeonpea thus contributing 31.43 per cent of area and 25.86 per cent production to the country with an average productivity of $450 \mathrm{~kg} \mathrm{ha}^{-1}$ (Anonymous, 2016). Low average productivity of this crop is mainly due to dry spell during vegetative stage, terminal drought at reproductive stage and the poor fertilizer management. Under such situation it is a big challenge for agricultural scientists to boost the yield of this crop.

Modern agronomic practices like drip irrigation and fertigation are the key factors as it not only saves the considerable amount of water and nutrients but also increases the yield of crop. Drip irrigation system has many advantages like water and nutrients can be applied precisely in the root zone of the crop at a low rate varying from 2-20 litres per hour.

It saves time and energy. It also saves the labour charges that are incurred on weeding as weed intensity is less in this method as compared to traditional method of irrigation. The quality of food grains / fruits is better under drip irrigation. Vimalendran (2013) has observed that drip irrigation increases the yield potential of crops by three times with the same amount of water and saves about 45 to 50 per cent of irrigation water and enhances the productivity around 40 per cent.

Drip fertigation helps to apply precise quantity of water soluble fertilizers along with the water directly in the active root zone of the crop where the concentration of active roots is high (Sivanappan et al., 1985). Therefore both water and nutrient can be saved in this technology and eventually increases crop productivity and quality as compared to conventional method.

Considering the above facts, the present field investigation was undertaken at the research farm of AICRP on Irrigation Water Management, Vasantrao Naik Marathwada
Krishi Vidyapeeth, Parbhani (MS) with an objective to study the effect of different irrigation and ferigation levels on growth and yield attributes of pigeonpea.

\section{Materials and Methods}

The soil of experimental field was high in clay content, slightly alkaline in reaction, normal in salt content, low in available soil nitrogen, medium in soil organic carbon and available soil phosphorus and very high in soil available potassium. The experiment was laid out in split plot design with four irrigation levels in main plots viz. $\mathrm{I}_{1}$ : Drip irrigation at 0.6 ETc, $\mathrm{I}_{2}$ : Drip irrigation at $0.8 \mathrm{ETc}, \mathrm{I}_{1}$ : Drip irrigation at $1.0 \mathrm{ETc}$ and $\mathrm{I}_{4}$ : Conventional method (surface irrigation of $60 \mathrm{~mm}$ each at critical growth stages like bud initiation, flowering and pod formation stage as per the situation) and in sub plots four fertigation levels viz. $\mathrm{F}_{1}$ : Control (no application of fertilizer), $\mathrm{F}_{2}: 80 \% \mathrm{RDF}, \mathrm{F}_{3}: 100 \% \mathrm{RDF}(25$ : $50: 25 \mathrm{NPK} \mathrm{kg} \mathrm{ha}^{-1}$ ) and $\mathrm{F}_{4}: 120 \% \mathrm{RDF}$ and replicated thrice on the same site with same randomization during both the years of investigation. The crop variety used was BDN-716 and was sown at the spacing of 150 $\mathrm{cm} \times 30 \mathrm{~cm}$ for drip treatments and at $90 \mathrm{~cm} \mathrm{x}$ $50 \mathrm{~cm}$ for conventional method on 25/6/2018 and 25/6/2019 during first and second year of study.

The application of irrigation through drip system was scheduled at alternate day on the basis of crop evapotranspiration (ETc) as per the different irrigation levels (0.6, 0.8 and 1.0 ETc). The different weather parameters viz., maximum and minimum temperature, maximum and minimum relative humidity, wind speed and bright sunshine hours were collected daily from the adjacent Agro meteorology observatory to calculate ETo (reference evapotranspiration) as per the FAO Penman Monteith method (Allen et al., 1998). The values of above mentioned weather 
parameters were incorporated in "Phule Jal" software developed by Mahatma Phule Krishi Vidyapeeth (MPKV), Rahuri to calculate the ETo (reference crop evapotranspiration) values on daily basis. Crop evapotranspiration i.e. net depth of irrigation water to be applied for each irrigation level was calculated by using the following formula,

ETc or D $n=($ ETo $\times$ Kc $) \times$ Wetted area $\left(\mathrm{m}^{2}\right)$

Where,

ETc $=$ Crop evapotranspiration $\left(\right.$ mm.day $\left.^{-1}\right)$

ETo $=$ Reference evapotranspiration $\left(\mathrm{mm}^{\mathrm{day}}{ }^{-}\right.$ 1)

$\mathrm{Kc}=$ Crop coefficient

The gross depth $(\mathrm{D} g)$ of water was calculated by following formula,

$$
(\mathrm{D} g)=\frac{\mathrm{D} n}{\mathrm{EU}}
$$

Where,

$\mathrm{D} g=$ Gross depth of irrigation $\left(\mathrm{mm} \mathrm{day}{ }^{-1}\right)$,

$\mathrm{D} n=$ Net depth of water to be applied $(\mathrm{mm}$ $\operatorname{day}^{-1}$ )

$\mathrm{EU}=$ Average emission uniformity in fraction

The volume of water to be applied per treatment plot was computed by an equation,

$\mathrm{V}=\mathrm{D} g \times \mathrm{A}$

Where,

$\mathrm{V}=$ Volume of water (litre day ${ }^{-1}$ ), $\mathrm{D} g=$ Gross depth of irrigation $\left(\mathrm{mm} \mathrm{day}^{-1}\right)$

$\mathrm{A}=$ Area of one plot, $\left(\mathrm{m}^{2}\right)$
The time of operation (hr.) of drip irrigation system for each treatment plot was calculated by using equation,

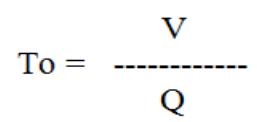

Where,

To $=$ Time of operation (hr.)

$\mathrm{V}=$ Volume of water applied to plot (litre day ${ }^{-}$

$\left.{ }^{1}\right)$

$\mathrm{Q}=$ Water applied to the plot (lph) i.e. $\mathrm{q} \times \mathrm{n}$

Where, $\mathrm{q}=$ average emitter discharge (lph)

$\mathrm{n}=$ number of emitters in the plot

The fertigation was given as per the schedule furnished in below table through soluble fertilizers viz. urea $(46 \% \quad \mathrm{~N})$, mono ammonium phosphate (12:61:0 NPK) and sulphate of potash (0:0:50 NPK) in 10 splits at an interval of ten days.

\section{Fertigation schedule}

The observations on growth and yield attributes of pigeonpea along with the seed yield plant $^{-1}(\mathrm{~g})$ were recorded at harvest and the data on maximum leaf area index was recorded at 120 DAS and statistically analyzed to evaluate the effect of different treatments.

\section{Results and Discussion}

\section{Growth attributes}

The data pertaining to growth attributes viz., plant height $(\mathrm{cm})$, number of branches plant ${ }^{-1}$, dry matter $\operatorname{plant}^{-1}(\mathrm{~g})$, and leaf area index $(\mathrm{g})$ as influenced by different treatments during 2018-19 and 2019-20 are furnished in Table 1 and the results of the same with proper justification is given below. 


\section{Effect of irrigation levels}

Drip irrigation scheduled at 1.0 ETc recorded significantly higher plant height $(\mathrm{cm})$, however it was comparable with 0.8 ETc. Similar trend was observed in respect of number of branches plant ${ }^{-1}$, dry matter plant ${ }^{-1}$ $(\mathrm{g})$, and leaf area index $(\mathrm{g})$. The higher growth attributes might be due to precise application of irrigation which had helped to maintain adequate moisture and aeration in the root zone of the crop and resulted in better transport of nutrient. These findings corroborate the earlier findings reported by Mahalakshmi et al., (2011), Gohel (2013) and Savani et al., (2017).

\section{Effect of fertigation levels}

Significantly higher values of growth attributes viz., plant height $(\mathrm{cm})$, number of branches plant ${ }^{-1}$ and dry matter plant ${ }^{-1}(\mathrm{~g})$ were observed with drip fertigation @ 30:60:30 NPK kg ha ${ }^{-1}$ (120\% RDF) closely followed by drip fertigation @ 25:50:25 NPK $\mathrm{kg} \mathrm{ha}^{-1}(100 \% \mathrm{RDF})$. Similar trend was also observed in respect of leaf area index $(\mathrm{g})$.

The increased plant height might be due to split application of nutrients through water soluble fertilizers in readily available form that might have augmented the production of growth regulators like auxins and cytokinins and this has helped in cell elongation and cell division and ultimately resulted in increased plant height. These results are in line with the earlier findings reported by Jeyajothi and Pazhanivelan (2017). Higher number of branches might be due to split application of fertigation through water soluble fertilizer which resulted in better transport of nutrient towards the activation of auxiliary bud that eventually put forth higher number of branches. These results are in accordance with the earlier findings reported by Patil and Padmani (2007). Taller plant height, higher number of branches, leaves and fruiting parts which eventually contributed in production of higher dry matter accumulation. These findings are in agreement with the earlier findings reported by Singh and Pal (2003).

\section{Yield attributes}

The data related to yield attributes viz., number of pods plant ${ }^{-1}$, pod weight plant ${ }^{-1}(\mathrm{~g})$, number of seeds pod $^{-1}$, pod length $(\mathrm{cm})$, seed yield plant $^{-1}$ (g) and seed index (g) as influenced by drip irrigation and fertigation treatments during both the years of investigation are presented in Table 2 and the results of the same with proper justification is given below.

Table.1 Fertigation schedule

\begin{tabular}{|c|c|c|c|c|c|c|}
\hline \multirow{3}{*}{$\begin{array}{c}\text { Duration } \\
\text { (Days) }\end{array}$} & \multirow{3}{*}{$\begin{array}{l}\text { No. of } \\
\text { splits }\end{array}$} & \multirow[t]{3}{*}{ Time of application } & \multicolumn{4}{|c|}{ Percent of fertilizer dose applied in } \\
\hline & & & \multicolumn{3}{|c|}{ Fertigation Method } & \multirow{2}{*}{$\begin{array}{c}\text { Conventional } \\
\text { method NPK \% }\end{array}$} \\
\hline & & & $\mathbf{N}$ & $\mathbf{P}$ & $\mathbf{K}$ & \\
\hline 01-30 & 2 & 10 and 20 DAS & 20 & 40 & - & \multirow{5}{*}{$\begin{array}{l}100 \% \text { NPK at the time } \\
\text { of sowing }\end{array}$} \\
\hline $31-60$ & 3 & 31,40 and 50 DAS & 30 & 30 & 25 & \\
\hline $61-90$ & 3 & 61,70 and 80 DAS & 30 & 30 & 40 & \\
\hline 91-120 & 2 & 91 and 110 DAS & 20 & - & 35 & \\
\hline \multicolumn{3}{|c|}{ Total } & 100 & 100 & 100 & \\
\hline
\end{tabular}


Table.2 Plant height $(\mathrm{cm})$, number of branches plant ${ }^{-1}$, dry matter plant ${ }^{-1}(\mathrm{~g})$, and leaf area index $(\mathrm{g})$ as influenced by different treatments during 2018-19 and 2019-20

\begin{tabular}{|c|c|c|c|c|c|c|c|c|}
\hline \multirow{2}{*}{$\begin{array}{c}\text { Treatments } \\
\text { Irrigation levels }\end{array}$} & \multicolumn{2}{|c|}{ Plant height (cm) } & \multicolumn{2}{|c|}{ Number of branches plant ${ }^{-1}$} & \multicolumn{2}{|c|}{ Dry matter plant ${ }^{-1}(g)$} & \multicolumn{2}{|c|}{ Leaf area index } \\
\hline & 2018-19 & 2019-20 & 2018-19 & 2019-20 & 2018-19 & 2019-20 & 2018-19 & 2019-20 \\
\hline$I_{1}: 0.6$ ETc & 173.62 & 211.04 & 34.42 & 44.13 & 516.93 & 580.58 & 4.08 & 4.08 \\
\hline$I_{2}: 0.8$ ETc & 184.14 & 223.39 & 39.05 & 47.23 & 576.84 & 661.73 & 4.96 & 4.96 \\
\hline$I_{3}: 1.0$ ETc & 190.13 & 229.01 & 42.33 & 50.20 & 615.40 & 696.97 & 5.46 & 5.46 \\
\hline$I_{4}:$ Conv. method & 165.25 & 200.09 & 28.65 & 35.45 & 410.86 & 500.64 & 3.56 & 3.56 \\
\hline S.E. \pm & 5.36 & 5.64 & 1.83 & 1.42 & 18.42 & 17.44 & - & - \\
\hline CD at $5 \%$ & 13.11 & 13.80 & 4.47 & 3.47 & 45.08 & 42.69 & - & - \\
\hline \multicolumn{9}{|l|}{ Fertigation levels } \\
\hline$F_{1}:$ Control & 161.10 & 197.59 & 30.75 & 32.99 & 361.08 & 423.48 & 3.45 & 3.45 \\
\hline $\mathrm{F}_{2}: \mathbf{8 0} \% \mathrm{RDF}$ & 175.67 & 215.73 & 35.32 & 44.56 & 526.21 & 606.98 & 4.57 & 4.57 \\
\hline$F_{3}: 100 \%$ RDF & 185.74 & 221.55 & 38.29 & 48.54 & 596.22 & 678.67 & 4.92 & 4.92 \\
\hline $\mathrm{F}_{4}: 120 \% \mathrm{RDF}$ & 190.62 & 228.66 & 40.08 & 50.92 & 636.50 & 730.79 & 5.11 & 5.11 \\
\hline S.E. \pm & 6.22 & 5.83 & 0.89 & 1.86 & 22.65 & 25.59 & - & - \\
\hline CD at $5 \%$ & 12.83 & 12.04 & 1.83 & 3.85 & 46.74 & 52.82 & - & - \\
\hline \multicolumn{9}{|l|}{ Interaction $(\mathbf{I} \times \mathbf{F})$} \\
\hline S.E. \pm & 12.03 & 11.57 & 2.32 & 3.53 & 43.34 & 47.64 & - & - \\
\hline CD at $5 \%$ & NS & NS & NS & NS & NS & NS & - & - \\
\hline General Mean & 178.28 & 215.88 & 36.11 & 44.25 & 530.01 & 609.98 & 4.52 & 4.52 \\
\hline
\end{tabular}


Table.3 Number of pods plant ${ }^{-1}$, pod weight plant ${ }^{-1}(\mathrm{~g})$, number of seeds pod ${ }^{-1}$, pod length $(\mathrm{cm})$, seed yield plant ${ }^{-1}(\mathrm{~g})$ and seed index $(\mathrm{g})$ as influenced by different treatments during 2018-19 and 2019-20

\begin{tabular}{|c|c|c|c|c|c|c|c|c|c|c|c|c|}
\hline \multirow{2}{*}{\begin{tabular}{|c|} 
Treatments \\
Irrigation levels
\end{tabular}} & \multicolumn{2}{|c|}{$\begin{array}{c}\text { Number of pods } \\
\text { plant }^{-1}\end{array}$} & \multicolumn{2}{|c|}{$\begin{array}{l}\text { Pod weight } \\
\text { plant }^{-1}(\mathrm{~g})\end{array}$} & \multicolumn{2}{|c|}{$\begin{array}{c}\text { Number of seeds } \\
\text { pod }^{-1}\end{array}$} & \multicolumn{2}{|c|}{ Pod length (cm) } & \multicolumn{2}{|c|}{$\begin{array}{c}\text { Seed yield plant } \\
(\mathrm{g})\end{array}$} & \multicolumn{2}{|c|}{ Seed index(g) } \\
\hline & $\begin{array}{c}2018- \\
19\end{array}$ & $\begin{array}{c}2019- \\
20\end{array}$ & $\begin{array}{c}2018- \\
19\end{array}$ & $\begin{array}{c}2019- \\
20\end{array}$ & $\begin{array}{c}2018- \\
19\end{array}$ & $\begin{array}{c}2019- \\
20\end{array}$ & $\begin{array}{c}2018- \\
19\end{array}$ & $\begin{array}{l}2019- \\
20\end{array}$ & $\begin{array}{c}\text { 2018- } \\
19\end{array}$ & $\begin{array}{l}2019- \\
20\end{array}$ & $\begin{array}{c}2018- \\
19\end{array}$ & $\begin{array}{c}2019 . \\
20\end{array}$ \\
\hline$I_{1}: 0.6$ ETc & 333.27 & 349.55 & 187.45 & 192.07 & 3.87 & 3.97 & 5.21 & 5.16 & 99.70 & 114.0 & 11.13 & 11.28 \\
\hline$I_{2}: 0.8$ ETc & 479.06 & 510.64 & 221.77 & 231.25 & 3.96 & 4.06 & 5.42 & 5.26 & 126.04 & 143.2 & 11.37 & 11.71 \\
\hline$I_{3}: 1.0$ ETc & 456.45 & 485.47 & 206.71 & 215.40 & 3.95 & 4.03 & 5.43 & 5.35 & 119.09 & 137.7 & 11.41 & 11.79 \\
\hline $\mathbf{I}_{4}:$ Conv. method & 180.03 & 211.95 & 115.71 & 139.91 & 3.81 & 3.91 & 4.63 & 5.14 & 67.64 & 87.9 & 11.06 & 11.12 \\
\hline S.E. \pm & 8.72 & 9.04 & 6.00 & 5.91 & 0.06 & 0.08 & 0.08 & 0.08 & 2.62 & 4.2 & 0.32 & 0.33 \\
\hline CD at $5 \%$ & 21.34 & 22.13 & 14.67 & 14.45 & NS & NS & NS & NS & 6.42 & 10.2 & NS & NS \\
\hline \multicolumn{13}{|l|}{ Fertigation levels } \\
\hline$F_{1}$ : Control & 220.34 & 247.75 & 121.14 & 135.47 & 3.78 & 3.93 & 5.02 & 5.08 & 70.31 & 75.2 & 10.92 & 10.94 \\
\hline $\mathrm{F}_{2}: \mathbf{8 0} \% \mathrm{RDF}$ & 414.48 & 441.88 & 204.12 & 216.60 & 3.89 & 3.97 & 5.14 & 5.19 & 114.20 & 137.5 & 11.29 & 11.56 \\
\hline $\mathrm{F}_{3}: 100 \% \mathrm{RDF}$ & 419.66 & 448.73 & 211.57 & 222.01 & 4.00 & 4.06 & 5.22 & 5.26 & 117.18 & 140.2 & 11.35 & 11.67 \\
\hline $\mathrm{F}_{4}: 120 \% \mathrm{RDF}$ & 394.34 & 419.25 & 194.81 & 206.35 & 3.92 & 4.01 & 5.31 & 5.38 & 110.78 & 130.0 & 11.40 & 11.74 \\
\hline S.E. \pm & 9.29 & 9.04 & 4.87 & 4.07 & 0.07 & 0.06 & 0.10 & 0.11 & 2.31 & 3.1 & 0.25 & 0.30 \\
\hline CD at $5 \%$ & 19.18 & 18.67 & 10.05 & 8.41 & NS & NS & NS & NS & 4.76 & 6.3 & NS & NS \\
\hline \multicolumn{13}{|l|}{ Interaction $(\mathbf{I} \times \mathbf{F})$} \\
\hline S.E. \pm & 18.30 & 18.09 & 10.35 & 9.20 & 0.12 & 0.12 & 0.19 & 0.21 & 4.78 & 6.8 & 0.54 & 0.61 \\
\hline CD at $5 \%$ & 37.78 & 37.33 & 21.36 & 19.00 & NS & NS & NS & NS & 9.87 & 13.9 & NS & NS \\
\hline General Mean & 362.20 & 389.40 & 182.91 & 194.66 & 3.90 & 3.99 & 5.17 & 5.23 & 103.12 & 120.7 & 11.24 & 11.48 \\
\hline
\end{tabular}


Table.4 Number of pods plant ${ }^{-1}$ of pigeonpea as influenced by interaction of irrigation and fertigation levels during 2018-19

\begin{tabular}{|c|c|c|c|c|}
\hline Treatments & \multicolumn{4}{|c|}{ Fertigation levels } \\
\hline Irrigation levels & $\mathrm{F}_{1}:$ Control & $\mathrm{F}_{2}: 80 \% \mathrm{RDF}$ & $\mathrm{F}_{3}: 100 \% \mathrm{RDF}$ & $\mathrm{F}_{4}: 120 \% \mathrm{RDF}$ \\
\hline $\mathbf{I}_{\mathbf{1}}: \mathbf{0 . 6}$ ETc & 252.9 & 348.6 & 361.1 & 370.5 \\
\hline $\mathbf{I}_{\mathbf{2}}: \mathbf{0 . 8}$ ETc & 243.1 & 568.7 & 582.6 & 521.8 \\
\hline $\mathbf{I}_{\mathbf{3}}: \mathbf{1 . 0}$ ETc & 270.3 & 566.1 & 557.4 & 431.9 \\
\hline $\mathbf{I}_{\mathbf{4}}:$ Conv. & 115.1 & 174.5 & 177.5 & 253.1 \\
method & & & & \\
\hline SE $\mathbf{5}$ & & 37.30 \\
\hline CD at 5 \% & & 37.78 \\
\hline
\end{tabular}

Table.5 Number of pods plant ${ }^{-1}$ of pigeonpea as influenced by interaction of irrigation and fertigation levels during 2019-20

\begin{tabular}{|c|c|c|c|c|}
\hline Treatments & \multicolumn{4}{|c|}{ Fertigation levels } \\
\hline Irrigation levels & $\mathrm{F}_{1}:$ Control & $\mathrm{F}_{2}: 80 \% \mathrm{RDF}$ & $\mathrm{F}_{3}: 100 \% \mathrm{RDF}$ & $\mathrm{F}_{4}: 120 \%$ RDF \\
\hline $\mathbf{I}_{\mathbf{1}}: \mathbf{0 . 6}$ ETc & 269.2 & 364.9 & 377.4 & 386.8 \\
\hline $\mathbf{I}_{\mathbf{2}}: \mathbf{0 . 8}$ ETc & 274.7 & 600.3 & 614.2 & 553.4 \\
\hline $\mathbf{I}_{\mathbf{3}}: \mathbf{1 . 0}$ ETc & 300.2 & 596.0 & 593.9 & 451.8 \\
\hline $\mathbf{I}_{\mathbf{4}}:$ Conv. & 147.0 & 206.4 & 209.5 & 285.0 \\
method & & & & \\
\hline SE \pm & & & 18.09 & \\
\hline CD at 5\% & & & 37.33 \\
\hline
\end{tabular}

Table.6 Mean pods weight ${ }^{-1}$ (g) of pigeonpea as influenced by interaction of irrigation and fertigation levels during 2018-19

\begin{tabular}{|c|c|c|c|c|}
\hline Treatments & \multicolumn{4}{|c|}{ Fertigation levels } \\
\hline Irrigation levels & $\mathrm{F}_{1}:$ Control & $\mathrm{F}_{2}: 80 \% \mathrm{RDF}$ & $\mathrm{F}_{3}: 100 \% \mathrm{RDF}$ & $\mathrm{F}_{4}: 120 \% \mathrm{RDF}$ \\
\hline $\mathbf{I}_{\mathbf{1}}: \mathbf{0 . 6}$ ETc & 136.5 & 192.7 & 210.5 & 210.0 \\
\hline $\mathbf{I}_{\mathbf{2}}: \mathbf{0 . 8}$ ETc & 130.4 & 258.4 & 263.1 & 235.3 \\
\hline $\mathbf{I}_{\mathbf{3}}: \mathbf{1 . 0}$ ETc & 136.5 & 250.6 & 245.7 & 194.1 \\
\hline $\mathbf{I}_{\mathbf{4}}:$ Conv. & 81.1 & 114.8 & 127.0 & 139.9 \\
\hline method & & & & \\
\hline SE \pm & & & 10.35 & \\
\hline CD at 5 \% & & & 21.36 \\
\hline
\end{tabular}


Table.7 Mean pods weight ${ }^{-1}(\mathrm{~g})$ of pigeonpea as influenced by interaction of irrigation and fertigation levels during 2019-20

\begin{tabular}{|c|c|c|c|c|}
\hline Treatments & \multicolumn{4}{|c|}{ Fertigation levels } \\
\hline Irrigation levels & $\mathrm{F}_{1}:$ Control & $\mathrm{F}_{2}: 80 \% \mathrm{RDF}$ & $\mathrm{F}_{3}: 100 \% \mathrm{RDF}$ & $\mathrm{F}_{4}: 120 \% \mathrm{RDF}$ \\
\hline $\mathbf{I}_{\mathbf{1}}: \mathbf{0 . 6}$ ETc & 142.8 & 197.9 & 212.5 & 215.0 \\
\hline $\mathbf{I}_{\mathbf{2}}: \mathbf{0 . 8}$ ETc & 144.9 & 266.7 & 269.4 & 244.0 \\
\hline $\mathbf{I}_{\mathbf{3}}: \mathbf{1 . 0}$ ETc & 148.8 & 257.8 & 252.1 & 202.9 \\
\hline $\mathbf{I}_{\mathbf{4}}:$ Conv. method & 102.2 & 139.9 & 154.0 & 163.5 \\
\hline SE \pm & \multicolumn{3}{|c|}{9.20} \\
\hline CD at 5 \% & \multicolumn{3}{|c|}{19.00} \\
\hline
\end{tabular}

Table.8 Mean seed yield plant ${ }^{-1}(\mathrm{~g})$ of pigeonpea as influenced by interaction of irrigation and fertigation levels during 2018-19

\begin{tabular}{|c|c|c|c|c|}
\hline Treatments & \multicolumn{4}{|c|}{ Fertigation levels } \\
\hline Irrigation levels & $\mathrm{F}_{1}$ : Control & $\mathrm{F}_{2}: 80 \% \mathrm{RDF}$ & $\mathrm{F}_{3}: 100 \% \mathrm{RDF}$ & $\mathrm{F}_{4}: 120 \% \mathrm{RDF}$ \\
\hline$I_{1}: 0.6$ ETc & 61.2 & 108.2 & 112.0 & 117.3 \\
\hline $\mathrm{I}_{2}: 0.8 \mathrm{ETc}$ & 82.6 & 141.8 & 145.9 & 133.8 \\
\hline$I_{3}: 1.0 \mathrm{ETc}$ & 83.8 & 139.4 & 138.2 & 115.0 \\
\hline $\begin{array}{c}\text { I }_{4}: \text { Conv. } \\
\text { method }\end{array}$ & 53.7 & 67.3 & 72.6 & 77.0 \\
\hline $\mathrm{SE} \pm$ & \multicolumn{4}{|c|}{4.78} \\
\hline CD at $5 \%$ & \multicolumn{4}{|c|}{9.87} \\
\hline
\end{tabular}

Table.9 Mean seed yield plant ${ }^{-1}(\mathrm{~g})$ of pigeonpea as influenced by interaction of irrigation and fertigation levels during 2019-20

\begin{tabular}{|c|c|c|c|c|}
\hline Treatments & \multicolumn{4}{|c|}{ Fertigation levels } \\
\hline Irrigation levels & $\mathrm{F}_{1}:$ Control & $\mathrm{F}_{2}: 80 \% \mathrm{RDF}$ & $\mathrm{F}_{3}: 100 \% \mathrm{RDF}$ & $\mathrm{F}_{4}: 120 \% \mathrm{RDF}$ \\
\hline $\mathbf{I}_{\mathbf{1}}: \mathbf{0 . 6}$ ETc & 74.20 & 122.48 & 127.91 & 131.48 \\
\hline $\mathbf{I}_{\mathbf{2}}: \mathbf{0 . 8}$ ETc & 79.80 & 168.42 & 170.09 & 154.41 \\
\hline $\mathbf{I}_{\mathbf{3}}: \mathbf{1 . 0}$ ETc & 87.65 & 167.22 & 165.27 & 130.77 \\
\hline $\mathbf{I}_{\mathbf{4}}:$ Conv. & 58.96 & 91.77 & 97.47 & 103.48 \\
method & & \multicolumn{3}{|c|}{6.8} \\
\hline SE $\mathbf{n}$ & & & 13.9 \\
\hline CD at 5 \% & & \multicolumn{3}{|c|}{} \\
\hline
\end{tabular}

Significant differences in mean pod length, number of seeds pod $^{-1}$ and seed index (hundred seed weight) of pigeonpea were not observed due to different irrigation schedules. The probable reason for this may be that agronomic practices could not influenced the basic varietal characters of the pigeonpea.

\section{Effect of fertigation levels}

The yield attributes like number of pods plant 1 , pod weight plant $^{-1}$ and seed yield plant $^{-1}$ were significantly influenced by drip fertigation levels during both the years of study. The application of 25:50:25 NPK kg 
ha-1 (100\% RDF) through drip irrigation in ten splits as per the fertigation schedule recorded significantly higher number of pods plant $^{-1}$, pod weight plant ${ }^{-1}$ and seed yield plant ${ }^{-}$ ${ }^{1}$ closely followed by drip fertigation @ 20:40:20 NPK kg ha ${ }^{-1}$ (80\% RDF) during both the years of experimentation. The increase in yield attributes might be due to split application of nutrients in adequate quantity through water soluble fertilizers in readily available form and this would have full filed the nutrient requirement of crop which in turn resulted in better translocation of assimilates from source to sink and thus resulted in increased yield attributes. Similarly Patil and Padmani (2007) also observed that fertilizing the pigeonpea crop with $75 \%$ and $100 \%$ RDF found equally effective and significantly superior over control in respect of yield attributes and yield. Yield attributing characters like pod length, number of seeds pod $^{-1}$ and seed index (hundred seed weight) of pigeonpea didn't showed significant differences due to fertigation levels. The probable reason for this might be the basic varietal characters of the pigeonpea crop that would have not been influenced due to fertigation treatments. Similarly, Avnish Kumar and Kushwaha (2006) also observed that hundred seed weight of pigeonpea didn't differ due to different rates of phosphorus application.

\section{Interaction effect}

Number of pods plant ${ }^{-1}$, pods weight plant $^{-1}$ and seed yield plant $^{-1}(\mathrm{~g})$ of pigeonpea were influenced significantly due to interaction effects of irrigation and fertigation levels during 2018-19 and 2019-20 (Table2). Treatment combination of irrigation at 0.8 ETc and $100 \%$ RDF through drip $\left(\mathrm{I}_{2} \mathrm{~F}_{3}\right)$ recorded significantly higher number of pods plant $^{-1}$, pods weight plant $^{-1}$ and seed yield plant $\left.^{-1}(\mathrm{~g})\right)$ during both years of experimentation, however it was at par with treatment combination of irrigation at 0.8 ETc and $80 \%$ RDF through drip $\left(\mathrm{I}_{2} \mathrm{~F}_{2}\right)$, irrigation at 1.0 ETc and $80 \%$ RDF through drip $\left(\mathrm{I}_{3} \mathrm{~F}_{2}\right)$ and irrigation at $1.0 \mathrm{ETc}$ and $100 \% \mathrm{RDF}$ through drip $\left(\mathrm{I}_{3} \mathrm{~F}_{3}\right)$ (Table 2A, 2B, 2C, 2D, 2E AND $2 \mathrm{~F})$. This might be due to frequent application of drip irrigation at alternate day which helped to maintain the optimum soil moisture in the root zone and split application of water soluble fertilizers through drip readily increased the availability of nutrients directly in the rhizosphere and helped in better translocation of nutrients, which in turn reflected in harnessing better growth parameters and these growth parameters might have contributed in higher yield attributes. These findings are in accordance with the earlier findings reported by Shruti and Aladakatti (2017).

From the findings of two years it can be concluded that scheduling of drip irrigation at 1.0 ETc at alternate day recorded higher growth attributes and was comparable with 0.8 ETc while drip fertigation with 30:60:30 NPK $\mathrm{kg} \mathrm{ha}{ }^{-1}$ in ten splits through water soluble fertilizers recorded higher growth attributes and was comparable with 25:50:25NPK kg ha ${ }^{1}$; whereas combination of drip irrigation at 0.8 ETc at alternate day and 25:50:25NPK NPK $\mathrm{kg} \mathrm{ha}^{-1}$ recorded higher yield attributes and seed yield per plant $(\mathrm{g})$ and was comparable with 0.8 ETc and 20:40:20 NPK kg ha ${ }^{-1}$.

\section{References}

Allen, R. G., L. S. Pereira, D. Raes and M. Smith (1998). Crop evapotranspiration - guidelines for computing crop water requirements. FAO irrigation and drainage paper 56. Food and Agriculture Organization, Rome.

Anonymous, (2016). Agricultural statistics at a glance, 2016. Government of India Ministry of Agriculture and Farmers Welfare, Department of Agriculture, 
Cooperation and Farmers Welfare, Directorate of Economics and Statistics, pp : 112-114.

Avnish Kumar and H. S. Kushwaha 2006. Response of pigeonpea (Cajanus cajan) to sources and levels of phosphorus under rainfed condition. Indian $J$. Agron. 51 (1) : 60-62.

Gohel, P. J. 2013. Feasibility of drip irrigation in rabi pigeonpea (Cajanus cajan (L) Millsp) with and without mulching under south Gujarat condition. M.Sc. (Agri.) Thesis, Navsari Agricultural University, Navsari, Gujarat.

Jeyajothi, R. and S. Pazhanivelan 2017. Dry matter, nutrient uptake and yield of short duration pigeonpea (Cajanus cajan L.) varieties under drip fertigation system. Int. J. Curr. Microbiol. App. Sci., 6 (11) : 39583965.

Mahalakshmi, K., K. Avil kumar, M. D. Reddy and M. Uma Devi. 2011. Response of rabi pigeonpea [Cajanus cajan (L.)] to different levels of drip irrigation. J. Res. ANGRAU. 39 (4):101-103.

Patil, A. B. and D. R. Padmani (2007). Effect of integrated nutrient management on growth and yield of pigeonpea (Cajanus cajan L. Millsp.). Int. J. Agric. Sci., 3 (2): 49-51.

Reddy, M. M., B. Padmaja, and L. J. Rao 2008. Response of Rabi pigeonpea to irrigation scheduling and weed management in Alfisols. J. Food Legumes, 21 (4): 237-239.

Sarkar, S., Panda, S., Yadav K. K and P.
Kandasamy 2018. Pigeonpea (Cajanus cajan) an important food legume in Indian scenario - A review. Legume Res. (online), LR-4021 : 1-10.

Savani N. G., R. B. Patel, B. M. Solia, J. M. Patel and V. P. Usadadiya 2017 Productivity and profitability of rabi pigeonpea increased through drip irrigation with mulch under South Gujarat condition. Int. J. Agri. Innov. and Res., 5 (5) : 758-760.

Shruti, M. Y. and Y. R Aladakatti 2017. Effect of drip irrigation and fertigation on yield, economics and water use efficiency of intra-hirsutum Bt cotton. J. Farm Sci., 30 (2) : 185-189.

Singh, T. and M. Pal 2003. Growth parameters, yield attributes and yield of pigeonpea as influenced by cropping systems and nitrogen + phosphorus levels. Ann. Agric. Res., 24 (4) : 755-759.

Sivanappan, R. K, O. Padmakumari and V. Kumar 1985. Drip Irrigation. Keerthi Publishing House, Coimbatore, India, pp. 75-80.

Snapp, S. S., Rohrbach, D. D., Simtowe, F., Freeman, H. A. 2002. Sustainable soil management options for Malawi: can small holder farmers grow more legumes? Agriculture, Ecosystems and Environment 91: 159-174.

Vimalendran, L. 2013.Optimizing drip irrigation and fertigation scheduling for long duration pigeonpea [Cajanus cajan (L.) Millsp.]. Ph.D. (Agri.) Thesis, Tamil Nadu Agricultural University, Coimbatore.

\section{How to cite this article:}

Gadade, G. D., D. N. Gokhale, U. M. Khodke and Kadale, A. S. 2021. Growth and yield attributes of Pigeonpea [Cajanus cajan (L.) Millsp.] as influenced by drip irrigation and fertigation levels. Int.J.Curr.Microbiol.App.Sci. 10(06): 318-327. doi: https://doi.org/10.20546/ijcmas.2021.1006.034 